\title{
Dinamika Hasil Fermentasi Rumen Pada Konsentrat yang Mengandung Suplemen Pakan Baru (SPB)
}

\section{Rumen Fermentation Dynamics of Concentrate Containing the New Feed Supplement}

\author{
Suharyono, Shintia NW Hardani dan Teguh Wahyono \\ Pusat Aplikasi Isotop dan Radiasi, BATAN \\ Jl. Lebak Bulus Raya No. 49, Jakarta 12440 \\ E-mail : suharyono@batan.go.id \\ Diterima 10-08-2015; Diterima dengan revisi 01-09-2015; Disetujui 02-10-2015
}

\begin{abstract}
ABSTRAK
Dinamika Hasil Fermentasi Rumen Pada Konsentrat yang Mengandung Suplemen Pakan Baru (SPB). Isotop ${ }^{32} \mathrm{P}$ digunakan untuk mengukur pembentukan protein mikroba dalam cairan rumen serta untuk mendapatkan formula suplemen pakan baru (SPB). Suplemen ini merupakan generasi baru untuk pakan ternak ruminansia yang dihasilkan oleh BATAN. Suplemen ini diaplikasikan untuk melengkapi fungsi konsentrat komersial sebagai pakan ruminansia. Tujuan penelitian ini adalah untuk untuk menguji SPB dan limbah kelapa sawit sebagai suplemen dan bahan pakan ruminansia serta mengetahui dinamika hasil fermentasi rumen konsentrat yang mengandung SPB. Kegiatan penelitian dibagi menjadi dua yaitu pengukuran pembentukan protein mikroba dalam cairan rumen dengan isotop ${ }^{32} \mathrm{P}$ dan pengukuran dinamika hasil fermentasi yang diinkubasi di dalam RUSITEC. Studi pertama menggunakan lima macam perlakuan yaitu : pelepah (P), tandan (TKS), kernel cangkang kelapa sawit $(\mathrm{KC}), \mathrm{P}+\mathrm{TKS}+\mathrm{KC}$ dan SPB. Peubah yang diamati adalah pembentukan protein mikroba (mg/jam/l). Perlakuan pakan pada studi kedua yaitu pakan kontrol (K) (konsentrat komersial); KS 30 (konsentrat komersial 70\% + SPB 30\%) dan KS 40 (konsentrat komersial $60 \%+$ SPB 40\%). Peubah yang diamati adalah hasil fermentasi rumen (24 jam inkubasi) berupa $\mathrm{pH}$, konsentrasi amonia $\left(\mathrm{N}-\mathrm{NH}_{3}\right)(\mathrm{mg} \%)$, volatile fatty acid (VFA) total $(\mathrm{mM})$, populasi protozoa $(\mathrm{sel} / \mathrm{ml})$, produksi gas total $(\mathrm{ml})$ dan produksi gas metan $\left(\mathrm{CH}_{4}\right)(\mathrm{ml})$. Dinamika fermentasi rumen direpresentasikan secara deskriptif pada enam hari inkubasi. Rata-rata peubah dianalisis menggunakan Rancangan Acak Lengkap (RAL) dengan 12 ulangan (enam hari inkubasi $\mathrm{x}$ dua ulangan) dilanjutkan dengan uji Duncan. Hasil pembentukan protein mikroba perlakuan $\mathrm{P}, \mathrm{TKS}, \mathrm{KC}, \mathrm{P}+\mathrm{TKS}+\mathrm{KC}$ dan SPB berturut-turut: 11,$90 ; 0,67 ; 1,87 ; 42.55$ dan $67,60 \mathrm{mg} / \mathrm{jam} / \mathrm{l}$. Hasil uji RUSITEC adalah nilai $\mathrm{pH}$ ketiga perlakuan berkisar normal antara 6,4-7,15. Dinamika konsentrasi $\mathrm{NH}_{3}$ dan produksi VFA total konsentrat komersial selalu lebih rendah dibandingkan KS 30 dan KS 40. Perlakuan KS 40 menghasilkan produksi VFA total sebesar $56,7 \%$ lebih tinggi dibanding konsentrat komersial. Penambahan SPB sebesar $40 \%$ pada konsentrat komersial dapat menstabilkan pH efluen RUSITEC. konsentrasi $\mathrm{NH}_{3}$, produksi VFA total dan produksi gas total cenderung tinggi tanpa meningkatkan produksi gas $\mathrm{CH}_{4}$ sebagai representasi dari efisiensi pakan ruminansia.
\end{abstract}

Kata kunci: Fermentasi rumen, konsentrat komersial, limbah kelapa sawit, RUSITEC

\section{ABSTRACT}

Rumen Fermentation Dynamics of Concentrate Containing the New Feed Supplement. The utilization of ${ }^{32} \mathrm{P}$ for measuring of microbial protein synthesis in rumen liquid has potential role for obtaining a new formule of feed supplement (SPB). New Feed Supplements (SPB) was a new generation of ruminant feed supplement produced by the National Nuclear Energy Agency (BATAN). This supplement was applied to complete commercial concentrate function as feed for ruminants. In vitro testing used semi continuous in vitro such as Rumen Simulation Technique (RUSITEC). The purpose of this study was to evaluate SPB as feed supplement and palm oil industry byproduct, and also to determine the 
dynamics of rumen fermentation from concentrate containing SPB. Two in vitro's analyzes that have been studied were ${ }^{32} \mathrm{P}$ incubation and RUSITEC's methods. ${ }^{32} \mathrm{P}$ in vitro's study used five treatments: palm oil leaf (P), palm oil bunches ( TKS), Palm oil shell kernel (KC), $\mathrm{P}+\mathrm{TKS}+\mathrm{KC}$ and SPB. Parameter's measurement was microbial protein synthesis $(\mathrm{mg} / \mathrm{h} / \mathrm{l})$. RUSITEC treatments were: control (K) (commercial concentrate); KS 30 (70\% commercial concentrate $+30 \% \mathrm{SPB})$ and KS $40(60 \%$ commercial concentrate + 40\% SPB). Observed variables were fermented rumen product (24 hours incubation) such as $\mathrm{pH}$, ammonia concentration $\left(\mathrm{NH}_{3}\right)(\mathrm{mg} / 100 \mathrm{ml})$, total volatile fatty acid (TVFA) (mM), total gas production $(\mathrm{ml} / \mathrm{d})$ and methane production $\left(\mathrm{CH}_{4}\right)(\mathrm{ml} / \mathrm{d})$. Rumen fermentation dynamics represented descriptively on six days incubation. The average variable was analyzed using completely randomized design with 12 replicates (six days incubation $\mathrm{x}$ two replications) followed by Duncan test. Higest microbial protein synthesis was on SPB compared with P, TKS, KC and $\mathrm{P}+\mathrm{TKS}+\mathrm{KC}$ (67.6 vs $11.9 ; 0,67 ; 1,87$ and $42.55 \mathrm{mg} / \mathrm{h} / \mathrm{l}$ respectively). The RUSITEC results were $\mathrm{pH}$ value of three treatments in normal range between 6.40 to 7.15 . The dynamics of $\mathrm{NH}_{3}$ concentration and TVFA production of commercial concentrates always lower than the KS 30 and KS 40. The KS 40 treatment resulted in TVFA production $56.7 \%$ higher than commercial concentrate $(\mathrm{P}<0.05)$. The addition of $40 \%$ SPB on commercial concentrate could stabilize the $\mathrm{pH}$ of RUSITEC effluent. $\mathrm{NH}_{3}$ concentration, TVFA and total gas production were higher than commercial concentrate without increasing $\mathrm{CH}_{4}$ gas production as a ruminant feed efficiency representation.

Keywords : Commercial concentrate, palm oil byproduct, rumen fermentation, RUSITEC.

\section{PENDAHULUAN}

Fungsi suplemen pakan ruminansia adalah mencukupi kebutuhan nutrisi untuk mengoptimalkan kinerja rumen. Mikroba rumen dapat bekerja optimal jika sumber nutrisi yang terdapat dalam pakan selalu tersedia dan mudah didegradasi. Sumber nutrisi tersebut dapat diperoleh dari hasil samping pertanian, industri pertanian dan pangan [1]. Penggunaan bahan pakan yang tidak berkompetisi dengan manusia merupakan syarat utama agar ketersediaan pakan tetap kontinyu. Kendala utama pakan limbah tersebut adalah tingkat degradasinya yang rendah meskipun memiliki kandungan nutrisi tinggi [2].

SUHARYONO [1] melaporkan bahwa Badan Tenaga Nuklir Nasional (BATAN) telah mengembangkan suplemen berbasis bahan limbah pertanian, industri pertanian dan pangan. Suplemen pakan tersebut adalah Urea Molases Multinutrien Blok (UMMB), Suplemen Pakan Multinutrien (SPM) dan Suplemen Pakan Multinutrien Tanpa Molases (SPMTM). Beberapa varian suplemen tersebut telah diuji menggunakan teknik radioisotop ${ }^{32} \mathrm{P}$ secara in vitro. Pada pengembangan selanjutnya, telah diformulasikan suplemen berupa Suplemen Pakan Baru (SPB). Suplemen ini merupakan pengembangan dari UMMB, SPM dan SPMTM. Pengembangan dilakukan untuk meminimalisir kendala bahan pakan di lapangan sehingga dibuat suplemen pakan berbasis lokal [1]. Penggunaan SPB dalam ransum bertujuan untuk mendukung penggunaan konsentrat komersial agar lebih efisien, efektif dan mudah dalam memperoleh bahan penyusunnya. SUHERMAN [3] melaporkan bahwa formula ransum yang tepat akan meningkatkan efisiensi pakan. Kandungan nutrisi yang tidak lengkap akan menurunkan produksi ternak.

Formula ransum yang tepat, mengandung nutrisi lengkap dan mampu meningkatkan efisiensi pakan perlu diuji secara bertahap di laboratorium sebelum aplikasi langsung di lapangan. Pengujian pakan secara in vitro dapat dilakukan dengan metode semi continous in vitro berupa Rumen Simulation Technique (RUSITEC). RUSITEC adalah salah satu pengujian menggunakan metode continous-culture untuk mengevaluasi pengaruh pakan terhadap dinamika produk fermentasi rumen [4]. Kelebihan RUSITEC adalah dapat digunakan untuk mengetahui 
gambaran dinamika proses fermentasi dalam periode yang panjang (beberapa minggu). Metode RUSITEC juga dipilih untuk mengevaluasi beberapa informasi penting sebelum melakukan riset secara in vivo [5]. Tujuan penelitian ini adalah 1) melakukan evaluasi biologis terhadap SPB dan limbah kelapa sawit sebagai bahan baku pakan lokal 2) untuk mengetahui dinamika hasil fermentasi rumen pada konsentrat ruminansia yang mengandung SPB.

\section{BAHAN DAN METODE}

\section{Evaluasi biologis limbah kelapa sawit dan SPB}

\section{Persiapan bahan} SPB

diperoleh dengan memformulasikan limbah industri kelapa sawit. Bahan limbah yang digunakan yaitu pelepah (P), tandan kelapa sawit (TKS) dan kernel cangkang $(\mathrm{KC})$. Bahan ini berasal dari PTPN XIII Kalimantan Timur. Bahan pakan dan SPB dikeringkan di oven suhu $60{ }^{\circ} \mathrm{C}$ dan digiling sampai ukuran $0.5 \mathrm{~mm}$. Kandungan nutrisi limbah industri kelapa sawit dan SPB dapat dilihat pada Tabel 1. dilakukan pada tabung kapasitas $30 \mathrm{ml}$ berisi media cairan rumen yang ditambahkan radioisotop ${ }^{32} \mathrm{P}$. Metode inkubasi menggunakan radioisotop ${ }^{32} \mathrm{P}$ dilakukan sesuai metode VAN NEVEL dan DEMEYER [6] yang dimodifikasi oleh HENDRATNO [7]. Aktivitas radioisotop yang digunakan adalah sekitar 1.000.000 $\mu \mathrm{Ci} / \mathrm{cpm}$. Inkubasi dilakukan selama 2 jam pada suhu $39^{\circ} \mathrm{C}$ dengan menggunakan $25 \mathrm{ml}$ cairan rumen pada masing-masing tabung yang telah diisi dengan sampel sebanyak 25 mg dalam BK.

Sentrifugasi dilakukan setelah proses inkubasi pada 3000 rpm selama 10 menit. Sentrifugasi dilakukan sebanyak tiga kali dengan tambahan aquades sehingga diperoleh endapan dan supernatan. Supernatan yang masih keruh disentrifugasi kembali pada kecepatan 12000 rpm selama 10 menit. Sentrifugasi juga dilakukan sebanyak tiga kali ulangan dengan tambahan aquades sehingga diperoleh endapan dan filtrat. Endapan diencerkan dengan akuades dan ditambahkan $\mathrm{HClO}_{4}$ kemudian didestruksi sampai jernih. Sampel endapan dan filtrat diencerkan kemudian diambil 2 $\mathrm{ml}$ ke dalam vial yang sudah ditambahkan 5

Tabel 1. Data kandungan nutrisi limbah kelapa sawit dan SPB.

\begin{tabular}{llcccccc}
\hline No. & Bahan & $\begin{array}{c}\text { BK } \\
(\%)\end{array}$ & Abu & PK & $\begin{array}{c}\text { LK } \\
\text { SK }\end{array}$ & SK & BETN \\
\hline 1 & Pelepah (P) & 91,8 & 5,62 & 4,66 & 0,78 & 40,82 & 41,80 \\
2 & TKS & 90,48 & 3,99 & 8,03 & 1,5 & 40,34 & 36,62 \\
3 & KC & 90,97 & 4,43 & 5,28 & 1,20 & 36,86 & 43,20 \\
4 & P+TKS + KC & 94,45 & 8,88 & 11,04 & 1,18 & 25,49 & 47,96 \\
5 & SPB & 86,98 & 29,31 & 17,20 & 16,48 & 2,13 & 34,88 \\
\hline
\end{tabular}

Keterangan: Hasil analisis proksimat Laboratorium Biokimia, Fakultas Peternakan UGM; TKS (Tandan Kelapa Sawit); KC (Kernel Cangkang); SPB (suplemen pakan baru); BK (bahan kering); PK (protein kasar); LK (lemak kasar); SK (serat kasar); BETN (bahan ekstrak tanpa nitrogen).

\section{Metode inkubasi in vitro menggunakan perunut ${ }^{32} \mathbf{P}$}

Cairan rumen untuk inkubasi diperoleh dari kerbau berfistula. Inkubasi $\mathrm{ml}$ akuades. Aktivitas radioisotop ${ }^{32} \mathrm{P}$ sebagai penanda aktivitas mikroba dicacah dengan Liquid Scintilation Counter (LSC). Peubah 
yang diamati adalah pembentukan protein mikroba (mg/jam/l).

\section{Rancangan percobaan}

Hasil pengukuran pembentukan protein mikroba pada kelima sampel (Tabel 1) dianalisis statistik menggunakan Rancangan Acak Lengkap (RAL) dengan lima ulangan. Rata-rata yang berbeda nyata diuji lanjut menggunakan uji Duncan [8]. Analisis variansi (ANOVA) dihitung menggunakan software SPSS 16.0.

\section{Evaluasi biologis konsentrat komersial yang mengandung SPB}

\section{Persiapan Bahan}

Penelitian ini membandingkan tiga perlakuan pakan, yaitu: kontrol (K) (konsentrat komersial); KS 30 (konsentrat komersial $70 \%+$ SPB 30\%) dan KS 40 (konsentrat komersial 60\% + SPB 40\%). Bahan pakan yang telah diformulasi dikeringkan di oven suhu $60{ }^{\circ} \mathrm{C}$ dan digiling sampai ukuran $0.5 \mathrm{~mm}$. Kandungan nutrisi pakan perlakuan dapat dilihat pada Tabel 2 .
BRECKENRIDGE [9] yang didiskripsikan detail pada KAJIKAWA et al. [10]. Inokulum dan solid rumen diperoleh dari kerbau rawa (Bubalus bubalis) jantan berfistula dengan berat bidup $300 \mathrm{~kg}$. Ransum kerbau seharihari berupa rumput lapangan dan konsentrat komersial dengan persentase pemberian 50:50 berdasar bahan kering (BK). Cairan dan solid rumen diperoleh dari fistula kerbau pada pagi hari sebelum diberi pakan. Cairan dan solid rumen dipisahkan dengan kain kassa empat lipatan. Inokulum yang digunakan untuk fermentasi adalah campuran cairan rumen kerbau dan saliva buatan [11] masing-masing sebanyak $400 \mathrm{ml}$. Solid rumen digunakan sebagai starter pada inkubasi hari pertama.

Total $800 \mathrm{ml}$ cairan inokulum, $75 \mathrm{~g}$ solid rumen dan $15 \mathrm{~g}$ sampel pakan diinkubasi pada hari pertama untuk setiap vessel. Sampel pakan dan solid rumen dimasukkan ke dalam kantong nilon berpori $50 \mu \mathrm{m}$. Pada hari kedua inkubasi, solid rumen diganti oleh sampel pakan. Pada hari ketiga inkubasi dan seterusnya, sampel pakan diganti setiap 48 jam sekali. Infusi

Tabel 2. Kandungan nutrisi bahan pakan dan ransum perlakuan penelitian

\begin{tabular}{lcccccc}
\hline \multicolumn{1}{c}{ Pakan } & BK & Abu & PK & LK & SK & BETN \\
& $\%$ & \multicolumn{2}{c}{$-\cdots$} & & \\
& 87,56 & 9,14 & 11,63 & 5 & 29,79 & 44,44 \\
Konsentrat komersial* & 87,39 & 15,19 & 13,25 & 3,62 & 22,56 & 36,34 \\
KS 30 & 87,33 & 17,21 & 14,99 & 3,37 & 21,38 & 35,48 \\
KS 40 & &
\end{tabular}

Keterangan : *hasil analisis proksimat Laboratorium Biokimia, Fakultas Peternakan UGM; BK (bahan kering); PK (protein kasar); LK (lemak kasar); SK (serat kasar); BETN (bahan ekstrak tanpa nitrogen); KS 30 (konsentrat komersial 70\% + SPB 30\%); KS 40 (konsentrat komersial 60\% + SPB 40\%).

\section{Metode semi continous in vitro dengan RUSITEC}

Kultur mikroba rumen campuran digunakan dan dipelihara dalam RUSITEC. Perlengkapan tabung fermentasi terdiri dari enam buah vessel kapasitas $800 \mathrm{ml}$. Prosedur penelitian mengacu pada CZERKAWSKI \& saliva buatan dilakukan secara kontinyu pada taraf flow rate $3 \% /$ jam. Inkubasi berlangsung selama 11 hari, lima hari pertama adalah fase adaptasi dilanjutkan pengukuran peubah fermentasi pada enam hari terakhir (hari ke 6-12). 


\section{Pengukuran peubah}

Peubah yang diamati adalah hasil fermentasi rumen (efluen) di dalam vessel RUSITEC (24 jam inkubasi) berupa $\mathrm{pH}$, konsentrasi amonia $\left(\mathrm{NH}_{3}\right)(\mathrm{mg} / 100 \mathrm{ml})$ [12], TVFA (mM) [13], produksi gas total (ml) dan produksi gas $\mathrm{CH}_{4}(\mathrm{ml})$. Gas hasil fermentasi yang dianalisis ditampung dalam gas bag (5 1 A SANSHIN ${ }^{\circledR}$. Produksi gas total diukur menggunakan gas meter sedangkan konsentrasi gas $\mathrm{CH}_{4}$ dianalisis menggunakan MRU VarioPlus gas analyzer.

\section{Rancangan percobaan}

Karakteristik fermentasi rumen direpresentasikan secara deskriptif pada enam hari terakhir. Rata-rata peubah dianalisis statistik menggunakan Rancangan Acak Lengkap (RAL) dengan 12 ulangan (enam hari inkubasi $\mathrm{x}$ dua ulangan). Ratarata yang berbeda nyata dilanjutkan dengan uji Duncan [8]. Analisis variansi (ANOVA) dihitung menggunakan software SPSS 16.0.

\section{HASIL DAN PEMBAHASAN}

\section{Penelitian 1. Evaluasi biologis limbah kelapa sawit dan SPB}

Hasil pengamatan pembentukan protein mikroba pada limbah kelapa sawit dan SPB yang diinkubasi dalam cairan rumen disajikan pada Gambar 1. Nilai pembentukan protein mikroba pada pakan perlakuan SPB lebih tinggi dibandingkan $\mathrm{P}$, TKS, KC dan P+TKS + KC. Faktor yang mempengarui tinggi rendahnya pembentukan protein mikroba dalam cairan rumen adalah intake bahan kering, pemberian nitrogen dan karbohidrat mudah tersedia, kandungan mineral dan vitamin serta kombinasi hijauan dan konsentrat di dalam pakan. Faktor yang lain adalah kondisi lingkungan rumen dan lancarnya aliran nutrien ke saluran pencernaan [14]. Dalam penelitian ini, faktor yang paling berpengaruh terhadap pertumbuhan protein mikroba adalah kandungan PK pakan, energi mudah tersedia dan mineral. Pada Tabel 1 dapat dilihat bahwa kandungan PK
SPB lebih tinggi dibandingkan $\mathrm{P}, \mathrm{TKS}, \mathrm{KC}$, dan $\mathrm{P}+\mathrm{TKS}+\mathrm{KC}$. Komposisi SPB yang digunakan hampir sama dengan UMMB dan SPM [1] Perbedaan terletak pada komposisi bahan yang dibuat berbasis bahan pakan lokal. Sumber nitrogen dalam SPB adalah bungkil kedelai, ampas kecap dan urea sedangkan molases dan onggok merupakan sumber karbohidrat. Molases mengandung Cobalt (Co) yang dibutuhkan mikroba rumen untuk menghasilkan vitamin B12 [1]. Co merupakan mikromineral essensial sedangkan Pospor (P) dan Sulpur (S) adalah makromineral esensial [15].

Suplemen pakan memberikan dampak positif terhadap peningkatan pembentukan protein mikroba dalam cairan rumen [1] dan peningkatan bobot badan sapi Bali, peranakan Ongole, Simental dan Friesian Holstein [16]. UDDIN et al. [17] melaporkan bahwa efisiensi pembentukan protein mikroba dipengaruhi oleh sumber energi, nutrien nitrogen dan sulfur yang diberikan serta kondisi lingkungan dalam rumen. Mikroba di dalam rumen merupakan salah satu faktor yang berpengaruh terhadap metabolisme pakan di dalam rumen. Mikroba akan tumbuh baik apabila di dalam ransum mengandung vitamin, mikro mineral dan protein dari bahan organik yang tercerna. Konsentrasi mineral $S$ dalam ransum berpengaruh terhadap hasil pembentukan protein mikroba dalam rumen. Jumlah $\mathrm{S}$ yang harus tersedia adalah $0,11-0,20 \%$ dari total ransum. Mineral S akan digunakan untuk memacu produksi asam amino metionin dan cystein. Penambahan urea dan $S$ dalam ransum harus sebanding karena pembentukan protein mikroba akan lebih rendah jika persentase pemberian urea lebih banyak. Perbandingan pemberian $\mathrm{N}$ dan $\mathrm{S}$ yang optimal dalam ransum adalah 10:1. Mineral Pospor (P) juga berperan dalam pembentukan protein mikroba yang berguna untuk menstimulasi produksi Adenosin Tripospat (ATP) dan asam nukleat (DNA dan RNA) oleh mikroba rumen. MAHFUZ et al. [18] melaporkan bahwa tingginya kecernaan nutrisi dari grup senyawa yang mengandung 
$\mathrm{P}$ dipengaruhi oleh penambahan $5 \mathrm{~g}$ TSP di dalam pakan kontrol. Penambahan $\mathrm{P}$ dalam ransum berperan sebagai mediator untuk peningkatan pencernaan dan metabolisme nutrien. Degradasi serat kasar dapat ditingkatkan karena dalam pakan ditambahkan P.
Inkubasi konsentrat komersial pada RUSITEC menghasilkan $\mathrm{pH}$ terendah sebesar 6,65 yaitu pada hari ke delapan sedangkan $\mathrm{pH}$ tertinggi sebesar 7,14 pada hari ke sebelas. Perlakuan KS 30 menghasilkan $\mathrm{pH}$ yang stabil berkisar 6,4 6,62. Perlakuan KS 40 menghasilkan nilai

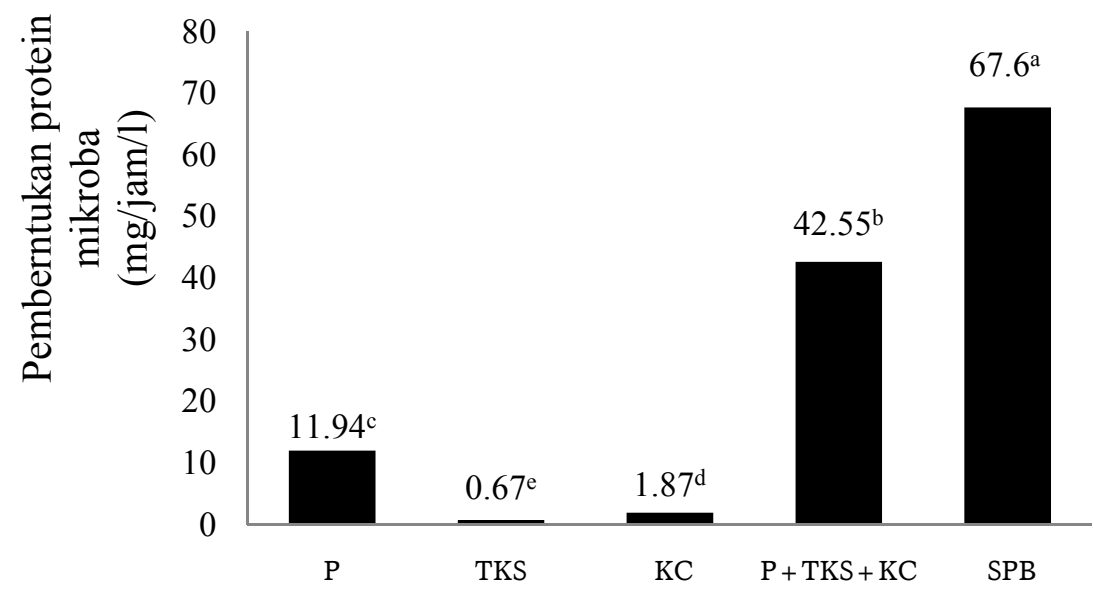

Gambar 1. Pembentukan protein mikroba hasil inkubasi pakan perlakuan (mg/jam/l). P (Pelepah); TKS (Tandan Kelapa Sawit); KC (Kernel Cangkang); SPB (suplemen pakan baru). Superscript yang berbeda menunjukkan perbedaan yang nyata.

\section{Evaluasi biologis konsentrat komersial yang mengandung SPB}

Dinamika hasil fermentasi rumen ketiga pakan perlakuan disajikan pada Gambar 2. Hasil fermentasi rumen tersebut merupakan produk inkubasi sampel pakan di dalam RUSITEC yang disebut efluen (hasil fermentasi). Dinamika yang diamati adalah hasil pengamatan pada hari ke 6-11. Hal tersebut disebabkan pada lima hari pertama inkubasi dianggap sebagai periode adaptasi pakan perlakuan. Rerata hasil fermentasi rumen juga disajikan pada Tabel 3. Pada tabel tersebut membandingkan rerata hasil inkubasi RUSITEC selama enam hari inkubasi dengan dua ulangan pada setiap perlakuan.

\section{pH}

Nilai $\mathrm{pH}$ efluen hasil fermentasi ketiga pakan perlakuan berkisar antara 6,40 - 7,15.
$\mathrm{pH}$ yang fluktuatif dengan nilai terendah pada hari ke sepuluh $(6,48)$ dan nilai tertinggi pada hari ke sebelas $(7,15)$ (Gambar 2A.). Rerata $\mathrm{pH}$ pada perlakuan KS 30 berbeda sangat signifikan dibandingkan pakan konsentrat komersial, namun pada KS 40 tidak menunjukkan perbedaan yang signifikan (Tabel 3).

Dinamika $\mathrm{pH}$ KS 30 cenderung lebih stabil dibandingkan konsentrat komersial dan KS 40. Nilai $\mathrm{pH}$ pada efluen konsentrat komersial cenderung tidak stabil pada hari ke 7-9. Hal tersebut membuktikan adanya perubahan kondisi efluen akibat perubahan dinamika ion hidrogen $(\mathrm{H})$. Pada kondisi anaerob, beberapa mikroba rumen akan membutuhkan energi dalam bentuk ATP dan akan melepas ion H. Sebagian mikroba lain termasuk bakteri propiogenik akan memerlukan ion $\mathrm{H}$. Penambahan SPB sebesar $30 \%$ mampu menurunkan $\mathrm{pH}$ 
Tabel 3. Rerata produk FERMENTASI rumen hasil uji RUSITEC pakan ruminansia yang mengandung SPB

\begin{tabular}{lrrrrr}
\hline \multirow{2}{*}{ Peubah } & \multicolumn{3}{c}{ Ransum perlakuan } & \multirow{2}{*}{ SEM } & Signifikansi \\
\cline { 2 - 3 } & \multicolumn{1}{c}{$\mathrm{K}$} & \multicolumn{1}{c}{ KS 30} & KS 40 & & \\
\hline $\mathrm{pH}$ & $6,96^{\mathrm{a}}$ & $6,50^{\mathrm{b}}$ & $6,71^{\mathrm{ab}}$ & 0,062 & $\mathrm{P}<0.01$ \\
$\mathrm{NH}_{3}(\mathrm{mg} / 100 \mathrm{ml})$ & $0,17^{\mathrm{c}}$ & $3,38^{\mathrm{b}}$ & $4,27^{\mathrm{a}}$ & 0,335 & $\mathrm{P}<0.01$ \\
$\mathrm{TVFA}(\mathrm{mM})$ & $45,00^{\mathrm{b}}$ & $66,50 \mathrm{a}^{\mathrm{b}}$ & $70,50^{\mathrm{a}}$ & 4,711 & $\mathrm{P}<0.05$ \\
Produksi gas total $(\mathrm{ml} /$ hari) & $539,17^{\mathrm{b}}$ & $915,83^{\mathrm{a}}$ & $767,92^{\mathrm{a}}$ & 44,489 & $\mathrm{P}<0.01$ \\
Produksi gas $\mathrm{CH}_{4}(\mathrm{ml} /$ hari) & $8,65^{\mathrm{b}}$ & $27,46^{\mathrm{a}}$ & $9,05^{\mathrm{b}}$ & 1,857 & $\mathrm{P}<0.01$ \\
\hline
\end{tabular}

Keterangan : $\mathrm{NH}_{3}$ (konsentrasi amonia); TVFA (Total Volatile Fatty Acid); kontrol (K) (konsentrat komersial); KS 30 (konsentrat komersial 70\% + SPB 30\%); KS 40 (konsentrat komersial $60 \%+$ SPB 40\%); superscript berbeda pada kolom yang sama menunjukkan perbedaan nyata $(\mathrm{P}<0.05)$ atau sangat nyata $(\mathrm{P}<0.01)$; SEM (standard error mean).

konsentrat, namun pada penambahan $40 \%$ justru tidak berpengaruh nyata (Tabel 3). Hal tersebut membuktikan bahwa tingkat optimal penambahan SPB dalam konsentrat untuk menurunkan nilai $\mathrm{pH}$ adalah $30 \%$, namun penambahan SPB $40 \%$ masih menghasilkan taraf $\mathrm{pH}$ normal. Nilai $\mathrm{pH}$ ketiga perlakuan pakan masih dalam kisaran netral. Kondisi pH normal (6-7) akan membuat populasi dan kinerja mikroba di dalam rumen menjadi lebih baik [4]. Nilai $\mathrm{pH}$ disebabkan oleh pengaruh laju alir saliva untuk suplai ke dalam vessel yaitu 4\%/jam [10]. Selain suplai saliva sebagai buffer selama fermentasi, mekanisme pengontrolan $\mathrm{pH}$ netral diduga pengaruh dari mikroba rumen yaitu pengguna laktat serta protozoa yang terus berjalan pada beberapa saat setelah pergantian sampel pakan [19].

Penurunan $\mathrm{pH}$ pada perlakuan KS 30 dapat dipengaruhi oleh menurunnya kandungan SK pada konsentrat setelah ditambahkan SPB (Tabel 2). Penambahan SPB dapat meningkatkan ketersediaan karbohidrat terlarut dalam konsentrat. Dalam penelitian XIANG-HUI et al. [20], suplementasi karbohidrat terlarut dapat menurunkan $\mathrm{pH}$ pada vessel RUSITEC pasca pergantian pakan $>12$ jam. Kehadiran bakteri pengguna laktat selama proses inkubasi juga membantu menjaga $\mathrm{pH}$ tetap netral [21]. JALC et al. [22] melakukan penelitian pemberian inokulan Enterococcus faecium dalam pakan silase jagung yang diinkubasi dengan teknik RUSITEC dapat meningkatkan $\mathrm{pH}$ dari 6.33 menjadi 6.45. Turunnya $\mathrm{pH}$ rumen berpengaruh terhadap aktivitas dan populasi bakteri selulolitik yang membantu proses fermentasi [23].

\section{Konsentrasi $\mathrm{NH}_{3}$}

Konsentrasi $\mathrm{NH}_{3}$ efluen RUSITEC pada perlakuan KS 40 menghasilkan rerata nilai tertinggi yaitu $4,27 \mathrm{mg} / 100 \mathrm{ml}$ sedangkan konsentrat komersial menghasilkan rerata terendah yaitu $0,17 \mathrm{mg} / 100 \mathrm{ml}$ (Tabel 3). Dinamika konsentrasi $\mathrm{NH}_{3}$ ketiga perlakuan menghasilkan dinamika yang berbeda-beda (Gambar 2B.). Konsentrasi $\mathrm{NH}_{3}$ perlakuan konsentrat komersial hanya terlihat pada hari ke enam inkubasi. Konsentrasi $\mathrm{NH}_{3}$ tidak ditemukan pada hari ke tujuh sampai akhir inkubasi. Dinamika konsentrasi $\mathrm{NH}_{3}$ efluen KS 40 lebih fluktuatif dibandingkan KS 30 dimana nilai tertinggi KS 40 diperoleh pada hari ke enam yaitu $5,17 \mathrm{mg} / 100 \mathrm{ml}$ sedangkan nilai tertinggi KS 30 diperoleh pada hari ke delapan sebesar $3,78 \mathrm{mg} / 100$ $\mathrm{ml}$. Hal tersebut dipengaruhi oleh perbedaan kandungan PK pada masing-masing ransum (Tabel 2). Pakan KS 40 mengandung PK tertinggi $(14,99 \%)$ diikuti oleh KS $30(13,25$ $\%)$ dan konsentrat komersial (11,63 \%). Konsentrasi $\mathrm{NH}_{3}$ yang tidak terditeksi pada 

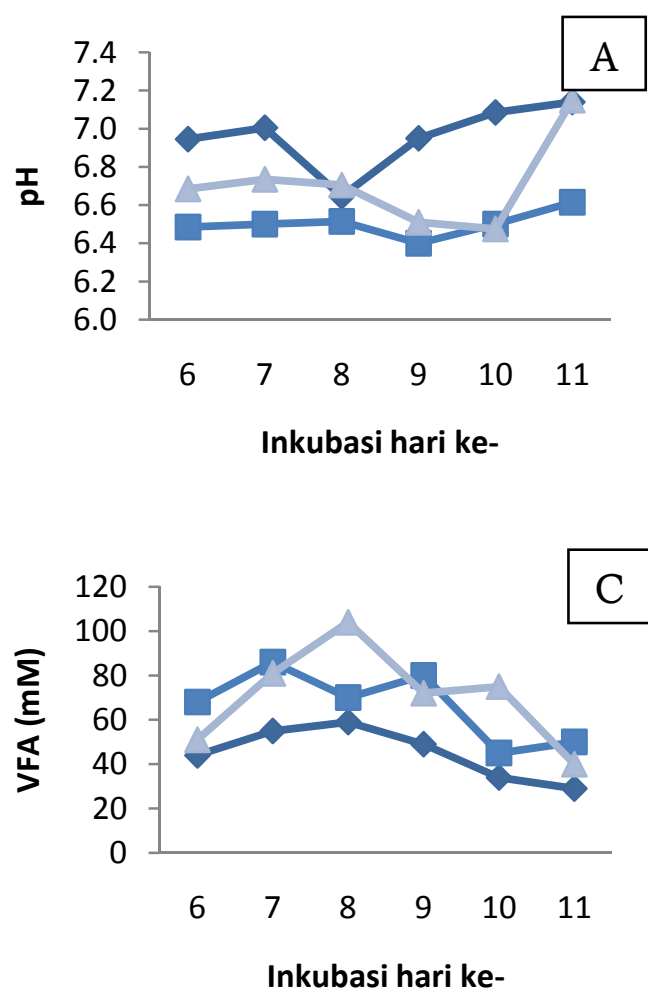
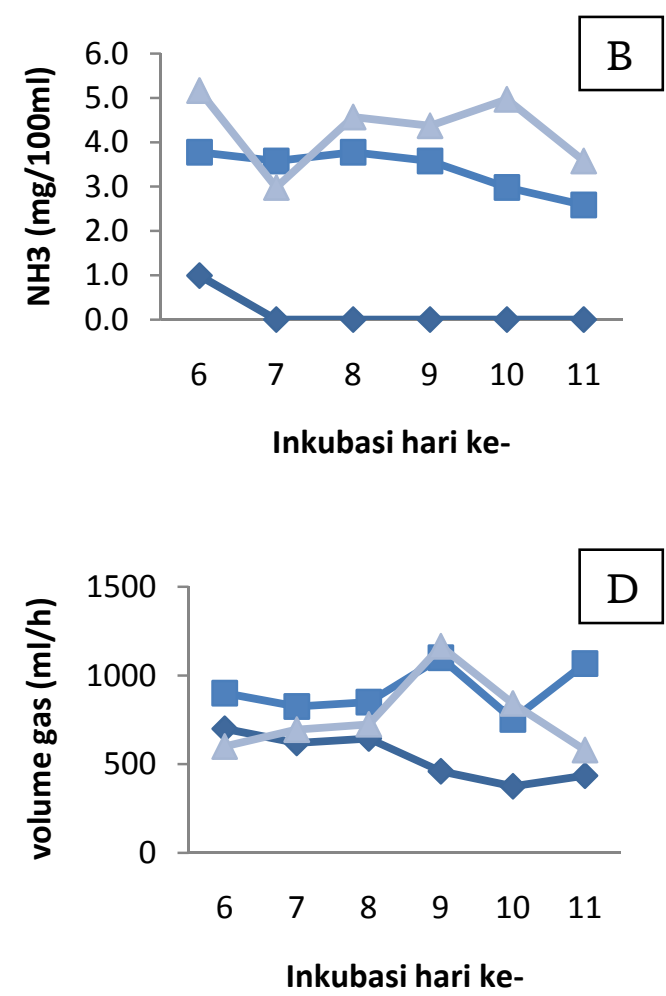



Gambar 2. Dinamika hasil fermentasi rumen konsentrat ruminansia yang mengandung SPB. A) $\mathrm{pH}$; B) $\mathrm{NH}_{3}(\mathrm{mg} / 100 \mathrm{ml})$; C) TVFA (mM); D) Volume gas total $(\mathrm{ml} / \mathrm{h}) ; \mathrm{E})$ Volume gas $\mathrm{CH}_{4}(\mathrm{ml} / \mathrm{h})$. Perlakuan $\mathrm{K}(-\mathbf{\Lambda}-)$ (konsentrat komersial); KS 30 (----) (konsentrat komersial 70\% + SPB $30 \%)$ dan KS $40(\cdots \bullet \cdots)$ (konsentrat komersial 60\% + SPB 40\%).

perlakuan konsentrat komersial disebabkan oleh ketersediaan PK yang rendah. Ketersediaan protein dan Nitrogen Non Protein (NPN) pada pakan akan didegradasi mikroba rumen menjadi $\mathrm{NH}_{3}$, peptida dan asam amino sehingga akan membentuk protein mikroba. WAGHORN [24] melaporkan bahwa oleh mikroba rumen, $\mathrm{NH}_{3}$ digabung menjadi asam amino dan akhirnya dibentuk menjadi protein mikroba.
Sekitar 50-80\% nitrogen mikroba berasal dari $\mathrm{NH}_{3}$ dan sisanya berasal dari peptida dan asam amino yang secara langsung bergabung menjadi protein mikroba.

Konsentrasi $\mathrm{NH}_{3}$ yang dihasilkan ketiga pakan perlakuan belum memenuhi konsentrasi optimal yang diperlukan mikroba dalam kultur tertutup yaitu sebesar $5 \mathrm{mg} / 100 \mathrm{ml}$ [25,26]. Konsentrasi yang rendah ini dapat disebabkan oleh kondisi 
pakan yang tidak seimbang yang direpresentasikan dalam dinamika nilai $\mathrm{pH}$ yang fluktuatif (Gambar 2A). OZTURK [27] melaporkan bahwa dalam teknik RUSITEC, konsentrasi $\mathrm{NH}_{3}$ tergantung dari keseimbangan antara deaminasi asam amino dan penggunaan $\mathrm{NH}_{3}$ oleh mikroba rumen. Pada teknik RUSITEC juga terjadi penggantian ransum setiap 24 jam sekali dan suplai saliva buatan untuk mendukung keseimbangan proses deaminasi dan pemanfaatan $\mathrm{NH}_{3}$ oleh mikroba rumen. Kuantitas penggunaan urea pada pakan juga sangat mempengaruhi konsentrasi $\mathrm{NH}_{3}$ pada efluen RUSITEC [4].

\section{Produksi TVFA}

Pada Gambar 2C dapat dilihat bahwa dinamika produksi TVFA pakan konsentrat komersial selalu paling rendah dibandingkan dua perlakuan lain pada enam hari pengamatan. Rerata produksi TVFA di dalam efluen konsentrat komersial adalah 45 $\mathrm{mM}$ dan secara signifikan lebih rendah dibandingkan perlakuan KS 40 (70,5 mM) (Tabel 3). Produksi TVFA yang rendah pada konsentrat komersial merupakan representasi dari belum optimalnya proses fermentasi pakan didalam rumen. Hal tersebut didukung oleh konsentrasi $\mathrm{NH}_{3}$ yang rendah selama masa inkubasi. Konsentrasi $\mathrm{NH}_{3}$ yang rendah akan berdampak pada menurunnya laju degradasi sumber $\mathrm{C}$ yang terdapat pada pakan untuk membentuk TVFA. Laju fermentasi berkorelasi dengan konsentrasi TVFA, sehingga penurunan konsentrasi TVFA merupakan refleksi dari menurunnya populasi mikroba rumen [28]. Produksi TVFA yang tinggi pada KS 40 membuktikan bahwa penambahan SPB sebesar $40 \%$ mampu meningkatkan ketersediaan karbohidrat terlarut bagi mikroba rumen. Fermentasi mikroorganisme rumen didahului oleh substrat yang mudah dicerna terlebih dahulu, nutrisi karbohidrat yang mudah dicerna akan cepat memproduksi TVFA [29].

Dinamika TVFA ketiga pakan perlakuan juga cenderung menurun secara bertahap setelah hari ke delapan inkubasi. Hal tersebut merepresentasikan bahwa populasi mikroba rumen semakin menurun seiring bertambahnya masa inkubasi. MACHMULLER et al. [30] melaporkan bahwa salah satu kendala dalam teknik RUSITEC adalah mempertahankan ekosistem mikroba terutama bakteri-bakteri anaerob dan protozoa. Hal tersebut direpresentasikan oleh menurunnya proporsi produk-produk fermentasi karbohidrat yang terkandung dalam pakan. Produksi TVFA pada perlakuan KS 30 dan KS 40 memiliki rerata yang sesuai standar sebesar $55.9 \mathrm{mM}$ [31]. Variasi produksi TVFA pada rumen kerbau rawa tergantung dari kandungan pakan dan nutrisi di dalamnya. Produksi TVFA pada rumen kerbau rawa yang diberi pakan sorgum sebagai pakan tunggal adalah $53.3 \mathrm{mM}$. Rumen kerbau yang diberi pakan jerami padi, jerami padi fermentasi dan konsentrat menghasilkan konsentrasi TVFA berturutturut 44.8, 48.9 dan $55.9 \mathrm{mM}$ [31].

\section{Produksi gas total}

Produksi gas total disajikan dalam bentuk dinamika volume gas dalam satuan waktu (ml/hari) (Gambar 2D). Dinamika produksi gas perlakuan konsentrat komersial cenderung menurun dengan volume gas terendah terjadi pada hari ke sepuluh yaitu $375 \mathrm{ml}$ sedangkan volume tertinggi terjadi pada hari pertama yaitu $700 \mathrm{ml}$. Dinamika produksi gas perlakuan KS 30 dan KS 40 cenderung fluktuatif setelah hari ke delapan inkubasi. Produksi gas perlakuan KS 30 dan KS 40 tertinggi terjadi pada hari ke sembilan yaitu sebesar $1100 \mathrm{ml}$ dan $1165 \mathrm{ml}$. Perlakuan konsentrat komersial menghasilkan gas total yang selalu lebih rendah dari kedua perlakuan lainnya selama enam hari inkubasi. Hal tersebut disebabkan oleh kinerja mikroba di dalam vessel dipengaruhi oleh kandungan nutrisi yang disuplai pakan [4]. Pada Tabel 2. Dapat dilihat bahwa kandungan PK konsentrat komersial selalu lebih rendah dibanding KS 30 dan KS 40. Perbedaan kandungan PK akan mempengaruhi konsentrasi $\mathrm{NH}_{3}$ yang 
dihasilkan selama proses inkubasi (Gambar 2B). Konsentrasi $\mathrm{NH}_{3}$ konsentrat komersial selalu lebih rendah dari KS 30 dan KS 40 sehingga akan mempengaruhi kinerja mikroba dalam melakukan fermentasi substrat pakan yang direpresentasikan dalam bentuk produksi gas.

Produksi gas juga berkaitan dengan produksi TVFA yang dihasilkan selama inkubasi. Hal tersebut dapat dilihat pada Tabel 3 yang menunjukkan rerata produksi TVFA perlakuan konsentrat komersial lebih rendah dibandingkan KS 30 dan KS 40. Total gas yang dihasilkan berasal dari fermentasi substrat secara langsung $\left(\mathrm{CO}_{2}\right.$ dan $\left.\mathrm{CH}_{4}\right)$ serta dari produksi gas tidak langsung melalui mekanisme buffering TVFA berupa gas $\mathrm{CO}_{2}$ yang dilepaskan dari buffer bikarbonat yang diproduksi selama proses fermentasi $[32,33]$. Rendahnya produksi gas pada konsentrat komersial juga dapat disebabkan oleh tingginya kandungan SK didalamnya (Tabel 2). Kandungan serat tinggi pada ransum dapat menyebabkan aktivitas mikroba rumen rendah pada 24 jam inkubasi pakan [34].

\section{Produksi gas $\mathrm{CH}_{4}$}

Produksi $\mathrm{CH}_{4}$ yang berlebih pada ternak ruminansia akan menurunkan efisiensi penggunaan energi yang terdapat dalam pakan. Kehilangan energi dalam bentuk gas $\mathrm{CH}_{4}$ adalah kerugian yang sangat besar karena kandungan energi $\mathrm{CH}_{4}$ cukup besar yaitu $55.22 \mathrm{MJ} / \mathrm{kg}$ [35]. Dinamika produksi gas $\mathrm{CH}_{4}$ yang dihasilkan pakan KS 30 selalu lebih tinggi dibandingkan dua perlakuan lainya (Gambar 2E). Rerata produksi $\mathrm{CH}_{4}$ juga lebih tinggi dibandingkan perlakuan KS 40 dan konsentrat komersial (Tabel 3). Hal ini membuktikan bahwa penambahan SPB 30\% dalam konsentrat komersial mampu mengoptimalkan pertumbuhan bakteri methanogen, namun hal ini perlu dibuktikan melalui uji yang lebih spesifik. Penambahan SPB sebesar $40 \%$ yang tidak mempengaruhi produksi gas $\mathrm{CH}_{4}$ diduga disebabkan oleh titik optimal pemberian SPB hanya pada taraf $30 \%$.
Produksi $\mathrm{CH}_{4}$ yang tinggi pada KS 30 juga disebabkan oleh tingginya produksi gas total hasil fermentasi (Tabel 3). Produksi $\mathrm{CH}_{4}$ enterik tergantung dari beberapa faktor diantaranya: 1) konsentrasi NDF dan Acid Detergent Fiber (ADF) dalam pakan [36] 2) umur dan tipe sumber serat yang dikonsumsi [37] serta 3) rasio asam asetat dan propionat yang terdapat pada produk fermentasi pakan [38]. Gas $\mathrm{CH}_{4}$ dihasilkan dari fermentasi pakan dalam kondisi anaerob. Semakin cepat pakan dicerna menyebabkan semakin sedikit karbon yang dikonversi menjadi gas $\mathrm{CH}_{4}$ [39].

\section{KESIMPULAN}

Pada uji inkubasi menggunakan perunut ${ }^{32} \mathrm{P}, \quad$ SPB menghasilkan nilai pembentukan protein mikroba tertinggi dibandingkan limbah kelapa sawit. Penambahan SPB sebesar $40 \%$ pada konsentrat komersial dapat mendukung fermentasi di dalam rumen secara optimal. $\mathrm{Hal}$ tersebut direpresentasikan oleh $\mathrm{pH}$ efluen RUSITEC yang berkisar normal. Konsentrasi $\mathrm{NH}_{3}$, produksi TVFA dan produksi gas total cenderung tinggi tanpa meningkatkan produksi gas $\mathrm{CH}_{4}$ sebagai representasi dari efisiensi pakan pada ruminansia. Pengujian melalui studi RUSITEC ini perlu didukung data-data in vivo dan uji lapang untuk memberikan rekomendasi formulasi pakan ruminansia terbaik.

\section{UCAPAN TERIMA KASIH}

Penulis mengucapkan terima kasih kepada Dr. Irawan Sugoro, bapak Edi Irawan Kosasih, Dinardi dan ibu Nuniek Lelananingtyas yang telah membantu proses penelitian. Penulis juga mengucapkan terima kasih kepada seluruh staf laboratorium Nutrisi Ternak Bidang Pertanian PAIR BATAN yang telah memberikan dukungan atas penelitian ini. 


\section{DAFTAR PUSTAKA}

1. SUHARYONO. Suplemen Pakan untuk Ternak Ruminansia dan Pengenalannya Kepada Peternak. Presentasi Ilmiah Peneliti Utama 16 Februari 2009. PATIR-BATAN (2009).

2. CLARK, J.H., M.R. MURPHY dan B.A. CROOKER. Supplying the protein needs of dairy cattle from byproduct feeds. J. Dairy Sci. 70: 1092-1109 (1987).

3. SUHERMAN, D. Kombinasi rumput gajah dan konsentrat dalam ransum terhadap kuantitas produksi susu sapi perah holstein. J. Penelitian UNIB. IX (2) 66-70 (2003).

4. WAHYONO, T., D.A. ASTUTI, I.K.G. WIRYAWAN, I. SUGORO dan SUHARYONO. Methane production and rumen fermentation characteristics of buffalo ration containing sorghum silage with rumen simulation technique (RUSITEC) methods. $5^{\text {th }}$ International Seminar of Tropical Animal Production Proceedings. 20$22^{\text {th }}$ October 2014. Yogyakarta. Indonesia (2015).

5. GARCÍA-GONZÁLEZ, R.J., S. S. GONZÁLEZ and S. LÓPEZ. Decrease of ruminal methane production in Rusitec fermenters through the addition of plant material from rhubarb (Rheum spp.) and alder buckthorn (Frangula alnus). J. Dairy Sci. 93: 3755-3763 (2010).

6. VAN NEVEL, C. and DEMEYER, D.L. The use uf ${ }^{32} \mathrm{P}$ to estimate microbiol synthesis in the rumen. $6^{\text {th }}$ symposium on energy metabolism of the EAAP, Stuttgart, Germany (1973).
7. HENDRATNO, C., Penggunaan ${ }^{32} \mathrm{P}$ dan ${ }^{35} \mathrm{~S}$ sebagai penanda pada pengukuran pembentukan masa mikroba rumen kerbau. Risalah Pertemuan Iliniah, Aplikasi Teknik Nuklir di Bidang Pertanian dan Peternakan, BATAN, Jakarta, 479491 (1985).

8. MATTJIK, A.A. and I.M. SUMERTAJAYA. Perancangan Percobaan. IPB Press. Bogor (2006).

9. CZERKAWSKI, J.W. and G. BRECKENRIDGE. Design and development of a long-term rumen simulation technique (RUSITEC). Br. J. Nutr. 38: 371-384 (1977).

10. KAJIKAWA, H., H. JIN, F. TERADA and T. SUGA. Operation and characteristics of newly improved and marketable artificial rumen (RUSITEC), Mem. Natl. Inst. Livest. Grassl. Sci. Japan 2 (2003).

11. MCDOUGALL, E.I. Studies on ruminant saliva. I. The composition and output of sheep's saliva. Biochem. J. 43: 99-109 (1948).

12. CONWAY, E.J. Microdiffusion Analysis and Volumetric Error, $3^{\text {rd }}$ ed. Crosby Lockwood, London, UK (1962).

13. AOAC. Official Methods of Analysis. Association of Official Analytical Chemists. Benjamin Franklin Station, Washington (2005).

14. PATHAK, A.K. Various factors affecting microbial protein synthesis in the rumen (Review). Vet. World 1(6): 186-189 (2008).

15. SUTTLE, N.F. Mineral Nutrution of Livestock. $4^{\text {th }}$ Eddition.CABI Head Office Nos Worthy Way Wallingford Oxfordshire UK. p: 1 and 223-224 (2010). 
16. SUHARYONO, H. SUTANTO, Y PURWANTI, M. MARTANTI, A. AGUS and U. RISTIANTO. The effect of urea molasses multinutrient and medicated block for beef cattle, beef and dairy cow. Atom Indonesia 40 (2), 77-87 (2014).

17. UDDIN, J.M., Z.H. KHANDAKER, M.J. KHAN and M.M.H. KHAN. Dynamics of microbial protein synthesis in the rumen (Review). Ann. Vet. Anim. Sci. (2015).

18. MAHFUZ S.U., M.R. CHOWDHURY, M.M.H. KHAN and A. BASET. Effect of triple super phosphate supplementation on degradability of rice straw and ammonia nitrogen concentration. Small Ruminant Res. 120 (1), 15-19 (2014).

19. KRISHNA. N.H. Produksi Gas Metan dan Pola Fermentasi Rumen Domba Lokal yang Diberi Pakan Komplit Mengandung Indigofera sp. Dan Limbah Tauge Menggunakan RUSITEC [tesis]. Bogor (ID): Institut Pertanian Bogor (2013).

20. XIANG-HUI, Z., L. CHAN-JUAN, L. CHAO-YUN and Y. JUN-HU. Effects of neutral detergent soluble fiber and sucrose supplementation on ruminal fermentation, microbial synthesis, and populations of ruminal cellulolytic bacteria using the Rumen Simulation Technique (RUSITEC). J. Integr. Agr. 12 (8), 1471-1480 (2013).

21. MACKIE, R.I. and F.M.C. GILCHRIST. Changes in lactate-producing and lactateutilizing bacteria in relation to $\mathrm{pH}$ in the rumen of sheep during stepwise adaptation to a highconcentrate diet. Appl Environ Microbiol., 38 (3), 422-430 (1979).
22. JALC, D., Z. VARADYOVAA, A. LAUKOVAA, P. HOMOLKAB and P. JANČÍK. Effect of inoculated corn silage on rumen fermentation and lipid metabolism in an artificial rumen (RUSITEC). Anim Feed Sci Tech., 152, 256-266 (2009).

23. MARTÍNEZ, M.E., M.J. RANILLA, M.L. TEJIDO, C. SARO and M.D. CARRO. Comparison of fermentation of diets of variable composition and microbial populations in the rumen of sheep and Rusitec fermenters. II. Protozoa population and diversity of bacterial communities., J. Dairy Sci. 93, 3699-3712 (2010).

24. WAGHORN, G. Beneficial and detrimental effects of dietary condensed tannins for sustainable sheep and goat productionProgress and challenges., Anim Feed Sci Tech. 147, 116-139 (2008).

25. WANAPAT, M. and P. ROWLINSON. Nutrition and feeding of swamp buffalo: feed resources and rumen approach. Ital J. Anim. Sci., 6 (Suppl. 2), 67-73 (2007).

26. WANAPAT, M., S. KANG and K. PHESATCHA. Enhancing buffalo production efficiency through rumen manipulation and nutrition. Buffalo Bull. 32 (1): 258-275 (2013).

27. ÖZTÜRK, H. Effects of chicory inulin on ruminal fermentation in vitro, Vet. J. Ankara Univ. 55, 79-82 (2009).

28. PAMUNGKAS, D., C.C. SEVILLA and U.M. LUSTRIA. Changes in rumen ecosystem and feed dry matter degradability of buffalo which received rumen content of cattle through cross inoculation. JITV. 11 (1): 24-33 (2006). 
29. CALSAMIGLIA, S., P.W. CARDOZO, A. FERRET and A. BACH. Changes in rumen microbial fermentation are due to a combined effect of type of diet and $\mathrm{pH}, J$. Anim. Sci. 86: 702711 (2008).

30. MACHMULLER, A., D.A. OSSOWSKI, $M$. WANNER and $M$. KREUZER. Potential of various fatty feeds to reduce methane release from rumen fermentation in vitro Rusitec, Anim Feed Sci Tech. 71: 117-130 (1998).

31. CHANTHAKHOUN, V. and M. WANAPAT. The in vitro gas production and ruminal fermentation of various feeds using rumen liquor from swamp buffalo and cattle, Asian J. Anim. Vet. Adv. 7 (1), 54-60 (2012).

32. GETACHEW, G., M. BLÜMMEL, H.P.S. MAKKAR and K. BECKER. In vitro gas measuring techniques for assessment of nutritional quality of feeds: a review. Anim Feed Sci. Tech., 72, 261-281 (1998).

33. JAYANEGARA, A., H.P.S. MAKKAR and BECKER K. Emisi metana dan fermentasi rumen in vitro ransum hay yang mengandung tanin murni pada konsentrasi rendah. Media Petern., 32 ,184-194 (2009).

34. KUMAR R, KAMRA DN, AGARWAL N and CHAUDHARY LC. In vitro methanogenesis and fermentation of feeds containing oil seed cakes with rumen liquor of buffalo. Asian-Aust.
J. Anim. Sci. 20 (8), 1196 - 1200 (2007).

35. ECKARD, R.J., GRAINGER, C. and C.A.M. DE KLEIN. Options for the abatement of methane and nitrous oxide from ruminant production: a review. Livest Sci. 130, 47-56 (2010).

36. SANTOSO, B., B. MWENYA, C. SAR and J. TAKAHASHI. Methane production and energy partition in sheep fed timothy hay silage or haybased dirts. JITV. 12: 27-33 (2007).

37. ARTHINGTON, J.D. dan W.F. BROWN. Estimation of feeding value of four tropical forage species at two stages of maturity, J. Anim. Sci. 83: 17261731 (2005).

38. MC ALLISTER, T.A., E.K. OKINE, G.W. MATHISON dan K.J. CHENG. Dietary, environmental and microbiological aspects of methane production in ruminants, Can. J. Anim. Sci. 76: 231-243 (1996).

39. WAHYONO, T., C.E. KUSUMANINGRUM dan SUHARYONO. Pengaruh pakan siap saji terhadap produksi gas metana secara in vitro dengan rumen simulation technique (RUSITEC). Prosiding Seminar Nasional Pendidikan dan Penelitian Biologi. FMIPA Universitas Pendidikan Indonesia, Bandung 28 Juni 2013. 247-252 (2013). 
Jurnal Ilmiah Aplikasi Isotop dan Radiasi

A Scientific Journal for The Applications of Isotopes and Radiation

ISSN 1907-0322

Vol. 11 No. 2 Desember 2015 